\title{
SCREENING OF VARIETY COLLECTIONS OF SUNFLOWER AND WINTER WHEAT FOR CADMIUM LOW ACCUMULATION
}

\author{
Fu Yuanzhi \\ Postgraduate Student \\ Sumy National Agrarian University, Sumy, Ukraine \\ Wu Liuliu \\ Postgraduate Student \\ Sumy National Agrarian University, Sumy, Ukraine \\ Trotsenko Volodymyr Ivanovych \\ Doctor (Agricultural Sciences), Professor \\ Sumy National Agrarian University, Sumy, Ukraine \\ ORCID: 0000-0001-8101-084 \\ vtrosenko@ukr.net \\ Zhatova Halyna Oleksiivna \\ PhD (Agricultural Sciences), Professor \\ Sumy National Agrarian University, Sumy, Ukraine \\ ORCID: 0000-0002-8606-6750 \\ gzhatova@ukr.net
}

Cadmium pollution in soil is a long-term and urgent problem, which directly affects the edible value of sunflower and winter wheat and may cause harm to human health. Breeding new varieties with low cadmium accumulation can effectively reduce the content of this element in seeds and fundamentally solve the risk of cadmium entering the human body through seeds and oil. In this paper, the method and significance of breeding sunflower and winter wheat with low cadmium accumulation were discussed.

Keywords: collection, samples, sunflower, winter wheat, $\mathrm{Cd}$ accumulation, breeding

DOI: https://doi.org/10.32845/agrobio.2019.3.7

Introduction. Cadmium (Cd) is a heavy metal widely known to be the most toxic in nature, and is listed as the primary heavy metal pollution source by the US Environmental Protection Agency (EPA). As an essential element for plants and animals, cadmium (Cd) naturally exists in the soil during the development of the parent material of soil, and usually does not harm the soil ecological environment $[1,2,3,4]$. With the continuous development of industry, agriculture and human activities, soil cadmium pollution may become more and more serious. The problem of soil $\mathrm{Cd}$ pollution caused by the unreasonable use of pesticides and fertilizers is increasingly serious. Crops absorb cadmium from the soil and accumulate in plants, affecting the yield or quality of crops, and further enter into the human's body through the food chains, affecting human health $[5,6,7]$. This has become a very serious environmental problem.

In order to prevent the accumulation of heavy metals in the soil, many countries in the world have formulated limit standards of heavy metals in some fertilizers. The EU countries do not have uniform heavy metal limits in chemical fertilizers, and they manage the fertilizers by their own laws and regulations. [9]. It is of great significance to study the mechanism of $\mathrm{Cd}$ tolerance of crops and select breeding of low $\mathrm{Cd}$ materials.

At present, various crops such as rice, maize, wheat, and cotton have been studied for their $\mathrm{Cd}$ tolerance mechanism and low-Cd material screening $[10,11,12]$ Compared with other cereals, wheat mainly accumulates $\mathrm{Cd}$ through the root system, and migrates to the above-ground part, and finally accumulates in the wheat grain [13]. It was reported that $\mathrm{Cd}$ is more toxic to wheat than other toxic metals. $\mathrm{Cd}$ toxicity reduces the absorption and transport of essential elements in wheat. The root growth and

morphology of wheat is seriously affected, resulting in the decrease of plant growth, biomass and grain yield [13]

Previous studies have shown that phosphate fertilizers often contain high amounts of heavy metals such as $\mathrm{Cd}$, and long-term application of phosphate fertilizers will inevitably lead to excessive $\mathrm{Cd}$ content in soil. But for conditions of Ukraine with average dose of phosphorus fertilizers $60 \mathrm{~kg}$ in the soil it is introduced annually $30-35 \mathrm{~g} / \mathrm{hectare}$ of cadmium. This is the factor that determines a rather high average concentration of $\mathrm{Cd}$ in the arable lands of Ukraine - about $0.15 \mathrm{mg} / \mathrm{kg}$ of soil.

Sunflower and winter wheat are of important economic crops in Ukraine. According to EU standards, sunflower cadmium accumulation should not be more than $0,05 \mathrm{mg} / \mathrm{k}$. However, $\mathrm{Cd}$ can be accumulated to a relatively high level with no disadvantage to its ontogenesis [14].

The problem must be confronted with reducing Cd-contaminated to be solved urgently. The fact that genetic variability exists with a species in the tendency to accumulate $\mathrm{Cd}$ provides an opportunity to utilize plant breeding to select for genetically low-Cd concentration.

Breeding of new sunflower and winter wheat varieties with low cadmium accumulation genotypes that can grow under different soil environmental conditions is a very effective solution. Although the breeding of new varieties resistant to cadmium is the fundamental method to solve the problem of low cadmium intake, the breeding process is long and complicated. The breeding process probably includes: 1) finding materials with low cadmium genes; 2) finding materials with high yield capacity, wide adaptability and other high quality materials besides low cadmium characteristics [15].

Вісник Сумського національного аграрного університету 
It is a practical and feasible way to select new varieties with low accumulation of $\mathrm{Cd}$ to reduce the absorption and accumulation of $\mathrm{Cd}$ in crops and thus reduce the content of $\mathrm{Cd}$ in agricultural products.

Aim of research: to study collection of winter wheat and sunflower and carried out the screening of samples with low cadmium accumulation.

Materials and methods. The research was carried out on the basis of educational research and production complex of Sumy National Agrarian University, located in the northeastern part of Forest-Steppe of Ukraine.

Plant sample collection includes 104 genotypes of sunflower (varieties, lines, hybrids) and 42 varieties of winter wheat. In green-house they were grown in plastic pots (for sunflower - 2 liter, for wheat -1 liter) filled with special substrate. Mixture soil content was: peat-substrate $(80 \%)$ and sand $(20 \%)$, source of $\mathrm{Cd}-\mathrm{CdSO}_{4}$, added to the substrate by spraying. Concentration of $\mathrm{Cd}$ in the substrate was $0,88 \mathrm{mg} / \mathrm{kg}$. In order to improve contact seeds coat with $\mathrm{Cd}$ we will add another part of $\mathrm{Cd}$ during sowing (with watering the pots). Finishing concentration of $\mathrm{Cd}$ in substrate was $1 \mathrm{mg} / \mathrm{kg}$. Cd content in root and shoot (winter wheat) and in stem and leaves (sunflower) was determined at stages of shooting (wheat) and flowering (sunflower). Subsamples were dried and then $\mathrm{Cd}$ concentration in them were determined by a spectrometer (CAS-120).

Results and discussion. The variety collection of 104 sunflower samples was formed. The largest part was the group of samples from Ukraine, the Russian Federation, the USA, Cuba, Bulgaria, Kazakhstan, Moldova provided by the National Centres of Genetic Resourses. The collection were supplemented by samples provided by the Institute of Oil Crops, the Institute of Agriculture of North-East of Ukraine and Sumy National Agrarian University.

It was established that the final phase of growth of vegetative mass of sunflower plants (more than $90 \%$ ) from the final values of the index (termination of vegetation) in the conditions of vegetation experiment was the beginning of flowering phase. The range of plant mass indices in the experiment ranged from 1,3 to $2.9 \mathrm{~g} /$ plant. The duration of the period of "seedlings-flowering" varied from 55 to 73 days. The values range of the cadmium content indicator in the above-ground part varied from 0,66 to $2.62 \mathrm{mg} / \mathrm{kg}$. The average content of cadmium in the aboveground part of the plants was 1.42 .

Within the collection, 4 groups with different level of cadmium accumulation in the above-ground part of plants were identified: "low" (less than $0.99 \mathrm{mg} / \mathrm{kg})$; "middle" (1.0 - $1.5 \mathrm{mg} / \mathrm{kg})$; "satisfactory " (1.6 - $2.0 \mathrm{mg} / \mathrm{kg}$ ); "high" (greater than $2.1 \mathrm{mg} / \mathrm{kg}$ ). Frequency of each groups in the collection was 14.5; 44.2; 32.7 and $8.7 \%$ respectively.

An additional parameter characterizing the overall ability of genotypes to absorb heavy metals (phyto-ameliorative selection direction) was the proportion of cadmium absorbed by the plants from the substrate. The average for this high-resistance group was $0.34 \%$; groups with good, satisfactory and low resistance respectively $0.49 ; 0.6$ and $0.83 \%$.

The variety collection of winter wheat, which included 41 varieties, was formed on the basis of crop regional distribution and its yield in the demonstration grounds. The collection includes varieties: 17 - ( originator -Selection-Genetic Institute National Center for Seed Research and Variety Studies), 6 (originator - Institute of Crop Science named after Yuriev), 5 Вісник Сумського національного аграрного університету
Bila Tserkva experimental- breeding station, 5 - Institute of Agriculture, 5 - Institute of Irrigated Agriculture, 2 - Myronivskyi Institute of Wheat named after Remeslo, 2 - Ivanivska experimental breeding station. The working collection was analyzed for the ability of plants to accumulate cadmium under the conditions of an analyzing background. The range of values of the cadmium content in plants varied from 0.94 to $2.02 \mathrm{mg} / \mathrm{kg}$, with an average of $1.42 \mathrm{mg} / \mathrm{kg}$ for the experiment. The average values of the cadmium content depending on the origin of the varieties were: $1.42 ; 1.47 ; 1.27 ; 1.58 ; 1.16$ and $1.24 \mathrm{mg} / \mathrm{kg}$, respectively (tabl.1).

The average values of the cadmium content

Table 1 depending on the origin of the varieties

\begin{tabular}{|c|c|}
\hline Variety & Cd content, $\mathrm{mg} / \mathrm{kg}$ \\
\hline \multicolumn{2}{|c|}{ Institute of Crop Science named after Yuriev } \\
\hline Alliance & $1.41 \pm 0.16$ \\
\hline Rozkishna & $1.4+0.02$ \\
\hline Pryvitna & $1.61+0.13$ \\
\hline Vidrada & $1.34+0.08$ \\
\hline Zdobna & $1.47+0.06$ \\
\hline Pryvablyva & $1.64+0.12$ \\
\hline \multicolumn{2}{|c|}{ Ivanivska experimental - breeding station } \\
\hline Fortova & $1.32+0.11$ \\
\hline Okhtyrchanka Juvileina & $1.16+0.03$ \\
\hline \multicolumn{2}{|c|}{ Bila Tserkva experimental- breeding station } \\
\hline Zorepad bilotserkivskyi & $1,14 \pm 0,05$ \\
\hline Romantyka & $1,61+0,16$ \\
\hline Shchedra Nyva & $1,02 \pm 0,01$ \\
\hline Tsarivna & $1,37 \pm 0,12$ \\
\hline Lybid & $1,24+0,15$ \\
\hline \multicolumn{2}{|c|}{ Myronivskyi Institute of Wheat named after Remes/o } \\
\hline Oberig myronivskyi & $1.39 \pm 0.12$ \\
\hline Svitanok myronivskyi & $0.94 \pm 0.01$ \\
\hline \multicolumn{2}{|c|}{ Institute of Agriculture } \\
\hline Kraevyd & $1.61+0.03$ \\
\hline Rusyava & $1.66 \pm 0.05$ \\
\hline Osyaina & $1.29+0.03$ \\
\hline Zaotar & $1.57+0.15$ \\
\hline Polisyanka & $1.51 \pm 0.07$ \\
\hline \multicolumn{2}{|c|}{ Institute of Irrigated Agriculture } \\
\hline Rosinka & $1.57 \pm 0.10$ \\
\hline Konka & $1.54+0.02$ \\
\hline Ovidiy & $1.11+0.09$ \\
\hline Maria & $1.21+0.08$ \\
\hline
\end{tabular}

Selection-Genetic Institute - National Center for Seed Research and Variety Studies

\begin{tabular}{|c|c|}
\hline \multicolumn{2}{|c|}{ and Variety Studies } \\
\hline Kantata odesska & $1.83 \pm 0.04$ \\
\hline Conata odesska & $1.53 \pm 0.02$ \\
\hline Duma odesska & $2.02 \pm 0.07$ \\
\hline Liga odesska & $1.29 \pm 0.02$ \\
\hline Oktava odesska & $0.91 \pm 0.01$ \\
\hline Optima odesska & $1.43 \pm 0.01$ \\
\hline Rodzinka odesska & $1.4 \pm 0.04$ \\
\hline Melody odesska & $0.95 \pm 0.10$ \\
\hline Pylypivka odesska & $1.43 \pm 0.12$ \\
\hline Hurt & $1.3 \pm 0.11$ \\
\hline Rozkvit & $1.69 \pm 0.02$ \\
\hline Sich & $1.76 \pm 0.11$ \\
\hline Khvala & $1.42 \pm 0.01$ \\
\hline Slaven & $1.05 \pm 0.01$ \\
\hline Klad & $1.59 \pm 0.09$ \\
\hline Krugozir & $1.62 \pm 0.03$ \\
\hline
\end{tabular}


The largest variation in cadmium content was observed in varieties of Selection-Genetic Institute. This group included three (among four) varieties with a minimum cadmium content ( $<1.00 \mathrm{mg} / \mathrm{kg}$ ), namely the Kubok - 0.96; Melody odeska - 0.95 and Octava odeska $-0.95 \mathrm{mg} / \mathrm{kg}$. However, in this group there were varieties with maximum cadmium accumulation rates (> $1.75 \mathrm{mg} / \mathrm{kg}$ ): the Duma odeska - 2.02; Cantata odeska - 1.83 and Sich $-1.76 \mathrm{mg} / \mathrm{kg}$.

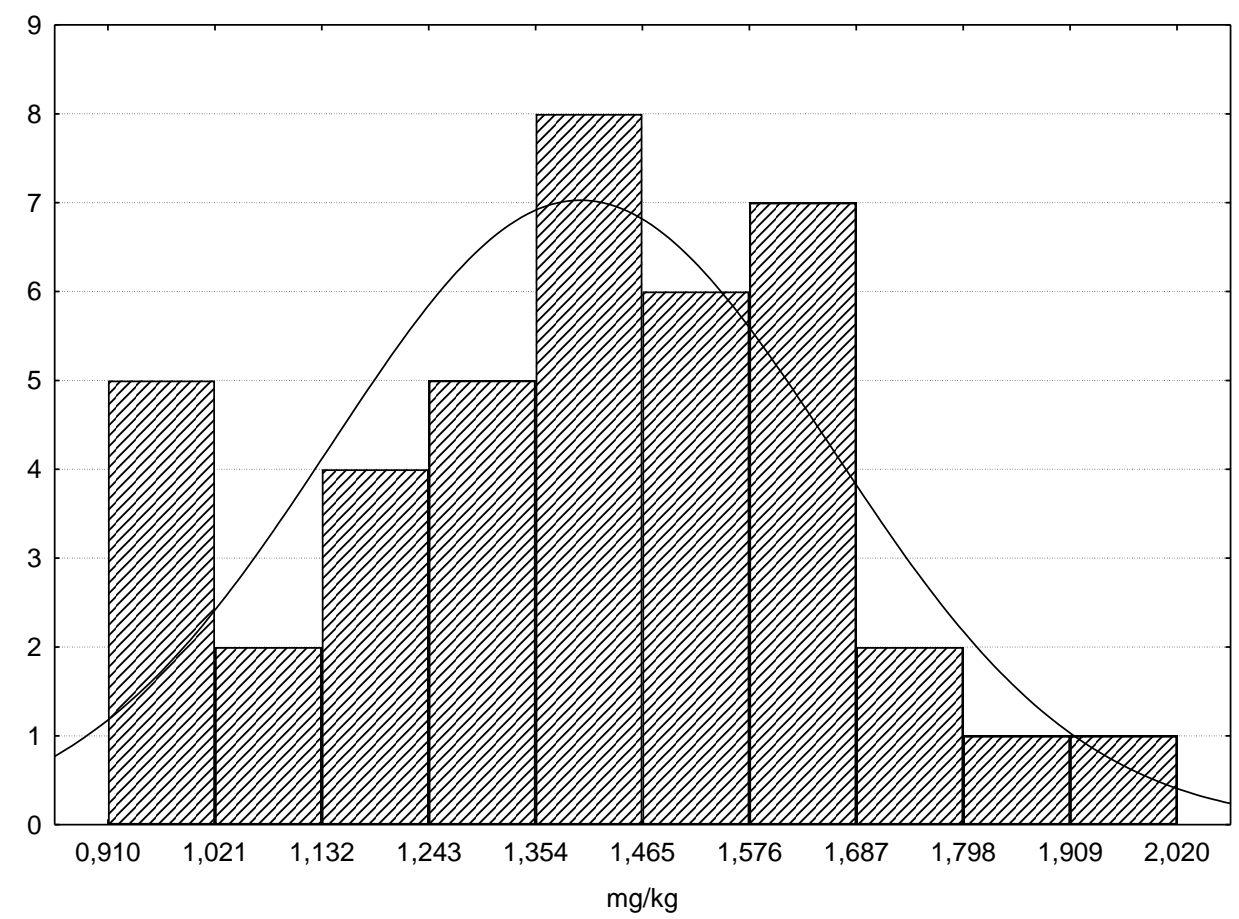

Fig. 1. Frequency distribution of the working collection of winter wheat varieties according to the indicator of cadmium content under conditions of anilizing background, 2019

Among the varieties of other establishments, the low rate of cadmium content with the minimum level of error was characterized by the Svitanok mironivsky $-0.94+0.01 \mathrm{mg} / \mathrm{kg}$. The general distribution of frequencies of the working collection of winter wheat varieties in terms of cadmium content is presented in Fig. 1.
Conclusions. As a result of the screening, the range of cadmium content in the samples of winter and sunflower varieties was determined which enables the formation of working collections and the introduction of breeding programs for varietal provision of technologies for obtaining environmentally safe products and phytomeliorative technologies.

\section{References:}

1. Adrees, M., Ali, S., Rizwan, M., Ibrahim, M., Abbas, F., Farid, M., \& Bharwana, S. A. (2015). The effect of excess copper on growth and physiology of important food crops. Environmental Science and Pollution Research, 22(11), 8148-8162.

2. Ali, S., Bharwana, S. A., Rizwan, M., Farid, M., Kanwal, S., Ali, Q., \& Khan, M. D. (2015). Fulvic acid mediates chromium $(\mathrm{Cr}$ ) tolerance in wheat (Triticum aestivum L.) through lowering of $\mathrm{Cr}$ uptake and improved antioxidant defense system. Environmental Science and Pollution Research, 22(14), 10601-10609.

3. Habiba, U., Ali, S., Farid, M., Shakoor, M. B., Rizwan, M., Ibrahim, M., \& Ali, B. (2014). EDTA enhanced plant growth, antioxidant defense system, and phytoextraction of copper by Brassica napus L. Environmental Science and Pollution Research, 22(2), 1534-1544.

4. Rizwan, M., Ali, S., Adrees, M., Rizvi, H., Zia-ur-Rehman, M. Hannan, F., \& Ok, Y. S. (2016). Cadmium stress in rice: toxic effects, tolerance mechanisms, and management: a critical review. Environmental Science and Pollution Research, 23(18), 1785917879.

5 Popova, L. P., Maslenkova, L. T., Yordanova, R. Y., Ivanova, A. P., Krantev, A. P., Szalai, G., \& Janda, T. (2009). Exogenous treatment with salicylic acid attenuates cadmium toxicity in pea seedlings. Plant Physiology and Biochemistry, 47(3), $224-231$.

7. Huang, M., Zhou, S., Sun B., \& Zhao, Q. (2008). Heavy metals in wheat grain: Assessment of potential health risk for inhabitants in Kunshan, China. Science of The Total Environment, 405(1-3), 54-61.

8. EFSA (2009) EFSA (European Food Safety Authority) (2009) Scientific Opinion of the Panel on Contaminants in the Food Chain on a request from the European Commission on cadmium in food. EFSA J 980, 1-139. 1172.

9. Surabhi, Rana. (2015). Plant Response towards Cadmium Toxicity: An Overview. Annals of Plant Sciences, 4(07), 1162-

10. Zhang, G., Fukami, M., \& Sekimoto, H. (2002). Difference between two wheat cultivars in cd and mineral nutrient uptake under different $\mathrm{Cd}$ levels. Chinese Journal of Applied Ecology, 13(4), 454-458.

11. Chen, C.H., Zhou, Q.X., Cai, Z., \& Wang, Y. Y. (2010). Effects of soil polycyclic musk and cadmium on pollutant uptake and biochemical responses of wheat (Triticum aestivum). Arch. Environ. Contam. Toxicol, 59, 564-573. 
12. Greger, M., \& Löfstedt, M. (2004). Comparison of Uptake and Distribution of Cadmium in Different Cultivars of Bread and Durum Wheat. Crop Science, 44(2), 501-507.

13. De Maria, S., Puschenreiter, M., \& Rivelli, A.R. (2013). Cadmium accumulation and physiological response of sunflower plants to Cd during the vegetative growing cycle. Plant Soil Environ., 59(6), 254-261.

14. Granta, C. A, Clarkeb, J. M., Duguidc, S., \& Chaneyd, R. L. (2008). Selection and breeding of plant cultivars to minimize cadmium accumulation. Science of the total environment, 301-310.

Фу Юанджі, аспірант, Сумський національний аграрний університет, м. Суми, Україна

Ву Люлю, аспірант, Сумський національний аграрний університет, м. Суми, Україна

Троценко В. І., доктор сільськогосподарських наук, профресор, Сумський національний аграрний університет, м. Суми, Україна

Жатова Г. О., кандидат сільськогосподарських наук, профессор, Сумський національний аграрний університет, м. Суми, Україна

СКРИНІНГ СОРТОВИХ КОЛЕКЦІЙ СОНЯШНИКУ ТА ОЗИМОї ПШЕНИЦІ ЩОДО НИЗЬКОЇ АКУМУЛЯЦІЇ КАДМІЮ

Кадмій (Cd) - важкий метал, який є одним з найбільш токсичних природних елементів. 3 розвитком промисловості та сільського господарства забруднення грунту кадмієм, спричиненого необгрунтованим використанням пестицидів та добрив, стає все більш загрозливим. Рослини поглинають кадмій з грунту і накопичують у вегетативних та генеративних органах, що впливає на врожайність та якість продукиії. В подальшому кадмій надходить в організм людини через харчові ланцюги, впливаючи на стан здоров'я.

Соняшник та озима пшениия є важливими економічними культурами в Україні. Забруднення кадмієм грунту є довгостроковою та нагальною проблемою, яка безпосередньо впливає на їстівну цінність соняшнику та озимої пшениці та може завдати шкоди здоров'ю людини. Відповідно до стандартів ЄC, накопичення кадмію в насінні соняшнику не повинно бути більше 0,05 мг/ке. Однак $C d$ може накопичуватися до відносно високого рівня. Проблема, пов'язана з забрудненням сільськогосподарської продукиії кадмієм потребує термінового вирішення.

Високий рівень генетичної мінливості видів, схильних до накопичення $\mathrm{Cd}$, дає можливість використовувати методи селекції рослин для відбору форм та зразків, що мають генетично обумовлену здатність до низької акумуляції цього елементу .

Отримання нових сортів соняшнику та озимої пшениці з генотипами, що мають низьку здатність до накопичення кадмію і які можуть рости у різних умовах ірунтового середовища, $є$ дуже ефективним рішенням. Хоча виведення нових сортів, стійких до акумуляції кадмію, є основним шляхом вирішення - тривалим і складним. Процес селекції, ймовірно, включає: 1) пошук вихідного матеріалу з вмістом генів, що відповідають за низьку акумуляцію кадмію; 2) пошук вихідного матеріалу з високою врожайністю, технологічними якостями та іншими характеристиками, крім здатності до низької акумуляиії кадмію .

Це практичний спосіб створення нових сортів з низьким нагромадженням $\mathrm{Cd}$ для зменшення поглинання та накопичення Cd в культурах забезпечить зниження вмісту $C d$ у сільськогосподарській продукиії.

Створення нових сортів із низькою акумуляцією кадмію може ефеективно знизити вміст иього елемента в насінні та принципово вирішити ризик потрапляння кадмію в організм людини через насіння та олію.

У иій роботі розглянуто спосіб та значення створення вихідного матеріалу соняшнику та озимої пшениці з низьким накопиченням кадмію.

Ключові слова: колекція, зразки, соняшник, озима пшениця, накопичення кадмію, селекція.

Фу Юанджи, аспирант, Сумской национальный аграрный университет, г. Сумы, Украина

Ву Люлю, аспирант, Сумской национальный аграрный университет, е. Сумы, Украина

Троценко В. И., доктор сельскохозяйственных наук, профессор, Сумской национальный аграрный университет, е. Сумы, Украина

Жатова Г. А., кандидат сельскохозяйственных наук, професссор, Сумской национальный аграрный университет, е. Сумы, Украина

СКРИНИНГ СОРТОВОЙ КОЛЛЕКЦИЙ ПОДСОЛНЕЧНИКА И ОЗИМОЙ ПШЕНИЦЫ ОТНОСИТЕЛЬНО НИЗКОЙ АККУ. МУЛЯЦИИ КАДМИЯ

Кадмий (Cd) - тяжельй металл, который является одним из наиболее токсичных природных элементов. С развитием промышленности и сельского хозяйства загрязнение почвы кадмием, вызванные необоснованным использованием пестицидов и удобрений становится все более угрожающим. Растения поглощают кадмий из почвы и накапливают в вегетативных и генеративных органах, что влияет на урожайность и качество продукции. В дальнейшем кадмий поступает в организм человека через пищевые цепи, влияя на состояние его здоровья.

Подсолнечник и озимая пшеница являются важными экономическими культурами в Украине. Загрязнение кадмием почвы является долгосрочной и насущной проблемой, которая непосредственно влияет на пищевую ценность подсолнечника и озимой пшеницы и может нанести вред здоровью человека. B соответствии со стандартами $E C$, накопление кадмия в семенах подсолнечника не должно превышать 0,05 мә/кә. Однако Cd может накапливаться до относительно высокого уровня. Проблема, связанная с загрязнением сельскохозяйственной продукции кадмием, требует срочного решения.

Высокий уровень генетической изменчивости видов, склонных к накоплению $\mathrm{Cd}$, дает возможность использовать Вісник Сумського національного аграрного університету 
методы селекции растений для отбора форм и образцов, имеющих генетически обусловленную способность к низкой аккумуляции этого элемента.

Получение новых сортов подсолнечника и озимой пшеницы с генотипами, имеющими низкую способность к накоплению кадмия и произрастанию в различных условиях, является очень эффрективным путем решения. Выведение новых сортов, устойчивых к аккумуляции кадмия, является основным путем решения - долгим и сложным. Процесс селлекции, вероятно, включает: 1) поиск исходного материала с содержанием генов, отвечающих за низкую аккумуляцию кадмия; 2) поиск исходного материала с высокой урожайностью, необходимыми технологическими качествами и другими характеристиками, за исключением способности к низкой аккумулящии кадмия.

Этот практичный способ создания новых сортов с низким накоплением Сd для уменьшения поглощения и накопления этого металла в культурах обеспечит снижение содержания элемента в сельскохозяйственной продукции. Создание новых сортов с низкой аккумуляцией кадмия может эффрективно снизить содержание этого элемента в семенах и принципиально решить риск попадания кадмия в организм человека через семена и масло.

В этой работе рассмотрены способ и значение создания исходного материала подсолнечника и озимой пшеницы с низким накоплением кадмия.

Ключевые слова: коллекция, образцы, подсолнечник, озимая пшеница, накопление кадмия, селекция.

Дата надходження до редакиії: 15.08.2019 p. 